\title{
Controlling in Transition Environments: Empirical Evidence from Croatia
}

Davor Špac, Lorena Mošnja-Škare*

Abstract:

The paper explores controlling developments in the particular environment of an economy involved in a transition process for almost two decades. The results presented in the paper were founded on the empirical analysis of the most successful Croatian companies, which were used as the sampling population. The presentation of controlling department existence in Croatian companies and the analysis of management perception of controlling importance were performed together with research on controlling information sources and users. All the information presented allowed us to make some conclusions about controlling development and to assess its future. Also, recent controlling developments were analyzed in the sample of Croatian SMEs to evaluate its implementation in this group of entities and to assess the factors of potential influence on its development level in a given enterprise, such as: size of the enterprise, management performance (ownermanagers or managers), intensity of accounting information use and relation to the business abroad.

The results were evaluated considering the controlling evolution in developed economies. Thus, the controlling evolution was monitored in the Croatian corporate sector, from its "registering" stage, still dominant on the scene, to its "innovation" stage. In addition to the current findings, future perspectives on controlling development flows in Croatia were also assessed.

Keywords: controlling, developments, transition, corporate sector

JEL: M19, M21, M41

DOI: $10.2478 / v 10033-009-0005-4$

\section{Introduction}

Companies from formerly planned economies started to compete in the open market by the end of the 1980s and at the beginning of 1990s when transition processes began. This paper analyzes the controlling developments in specific circumstances of a transitional economy like Croatian, after almost two decades of transition.

The study used the most successful Croatian companies as its sample. Also, we explored the controlling implementation in SMEs, the group of enterprises that make up $98 \%$ of business entities in Croatia, as in other countries in transition. Based on research results dating from $2005 / 2006$, together with Osmanagić-Bedenik's results from 2001, estimations of further controlling developments were also included.
In this way, controlling development in Croatian corporate sector was monitored starting from its early "registering" phase towards its "innovation" phase in the future, as was its path in developed economies. After considering various theoretical backgrounds, controlling evolution in the world, stage by stage, is presented in short to better understand its growing
* Davor Špac
Croatia Telecom Inc, Croatia
e-mail: davor.spac@t.ht.hr
Lorena Mošnja-Škare
University "Juraj Dobrila"
Department of Economics \& Turism
e-mail:Imosnja@efpu.hr 
function in a transitional economy like that of Croatia. Since there has been no systematic research on this topic in Croatia, the results should be considered while accounting for the limitations of the present scholars' work. With regard to the role of controlling in contemporary business operation in Croatian enterprises, there are still many relevant fields for further research, especially on possible improvements in its practice as well as the educational sector.

\section{Controlling - Theoretical Backgrounds}

At present, controlling is the focus of much scholarly research. Some authors define controlling as a "functional management instrument that supports the entrepreneurial process of leading and decisions through defined analysis and presentation of information" (Preisler and Peemoller 1990, p. 16). It is also understood as a "function in the management system that increases efficiency and in such a way makes it possible to cope with changes inside and outside the company" (Weber 1993, p. 46). Also, Weber J., together with other authors (Kupper, H.U. and Zund, A) defines controlling as management support that provides relevant knowledge about important facts and methods. According to the International Group of Controlling, "Controllers design and accompany the management process of defining goals, planning and controlling and thus have a joint responsibility with the management to reach objectives. This means:

- Controllers ensure the transparency of business results, finance, processes and strategy and thus contribute to higher economic effectiveness.

- Controllers co-ordinate sub-targets and related plans in a holistic way and organize a reportingsystem that is future-oriented and covers the enterprise as a whole.

- Controllers moderate and design the controlling process of defining goals, planning and management control so that every decision maker can act in accordance with agreed upon objectives.

- Controllers provide managers with all relevant controlling information.
- Controllers develop and maintain controlling systems."

It is obvious that controlling is strictly related to management. Management is responsible for the company's success and controlling is responsible for defining the steps to achieve it, as well as for monitoring these processes. Controlling coordinates all management functions (from planning through organizing, motivating and leading to control) and all the company's departments. The purpose of this horizontal and vertical coordination is the spread of the company's goals throughout the company. Controlling has the task of presenting the company's goals to all of its departments, to define the steps to achieve these goals and to control if the steps stick to the plan by analyzing variations in the processes, finding their reasons and defining how to minimize them. Controlling helps management in performing its functions by providing the necessary information from different sources - inside and outside the company, avoiding in such a way unexpected influences on business continuity towards company's goals. "In general, surprise is a bad thing, both inside and outside the company..." (Parfet 2000, p. 486).

In theory and practice, controlling is often mixed with accounting (especially management accounting - see more in Ryan 1995; Simons 1999; McWatters et all. 2001 , etc.). "A fundamental theme in management accounting is that firms use accounting systems to serve two broad objectives: facilitate decision making and mitigate control problems. - Demski and Feltham (1976), Baiman and Demski (1980), Christensen (1981), Baiman and Evans (1983), Penno (1984) Baiman and Sivaramakrishnan (1991), and Antle and Fellingham (1995) are examples of some early studies that highlight distinct control and decision-facilitating roles for accounting information." (Indjejikian and Matejka 2006, p. 849). At its beginning, controlling was a part of the accounting system and their tasks were very similar, but fast changes in business environments presented a new dimension that produced the main task of controlling. This task was the prediction of future changes in order to keep the company prepared before they actually happen. "Accrual accounting is a formalized anticipatory statement of stocks and 
flows... These accruals, however, are surely not happenstance. Rather, they are estimates - estimates that can be interpreted as expectations..." (Demski 2004, p. 519). Although the most important source of information for controlling is still considered to be the accounting system, other sources inside (other departments) and outside the company are necessary in the contemporary environment. Controlling is focused not only on measurable (numeric) variables but also on immeasurable ones (such motivation, customer satisfaction and similar), as well as defining deviations and the reasons for their appearance. In other words, a multifunctional approach and quality variables analysis are inevitable in fulfilling the controlling "navigator" purpose.

In this paper, we tried to track the controlling development process from the "registrator" towards the "innovator" in transition environments. We explored its current presence and organization in the most successful Croatian companies, while evaluating its future developments in relation to the demand for employees in controlling. We particularly stressed the controlling developments in Croatian SMEs, since they presented $98 \%$ of the Croatian enterprises that arose during the transition period as the result of privatization and breaking up of the large enterprises and the self-employment of many people who lost their jobs in the process. Most were usually very small entities featuring an owner that oversaw management, occasionally using accounting information to make business decisions and mostly acting within the national market. It was interesting how controlling could develop in such environments, keeping in mind underlying theories of its development as discussed above. Therefore, we developed a set of hypotheses that we have empirically tested in chapter 5 on the sample of Croatian enterprises:

H1: Controlling implementation is positively associated with the intensity of accounting information use.

H2: Controlling implementation grows with the enterprise's size.

H3: Controlling implementation increases if the enterprise is somehow related to business abroad.
H4: Controlling implementation increases if the owners are not performing the management function at the same time.

\section{Methods}

There were several common scientific methods combined in this research. A historical method was used for the presentation of controlling development. The inductive-deductive method allowed us to make scientific conclusions based on the data collected mainly by the direct observation method and the method of group inquiry. Statistical methods were employed to present the distribution of variables in the sample.

We have performed the structural analysis and have also tested the hypotheses by means of logit regression (software: SHAZAM Professional Edition). Controlling implementation (CONTROLC) was the dependent variable (1 for developed or developing controlling versus 0 for not developed), and four independent variables followed:

INTENSIC $=$ intensity of accounting information use (1 for regular or 0 for occasional use)

SIZEC=enterprise's size ( 1 for middle-sized or 0 for small according to Croatian Accounting Act criteria, NN 90/92)

$A B R O A D C=$ relation to the business abroad $(1$ if it exists or 0 if it doesn't exist)

MANAGC $=$ management function performance $(1$ by manager or 0 by owner him/herself).

All variables in the model, both dependent and independent, were dummy variables.

We tried to assess the probability of controlling implementation (CONTROLC or $\mathrm{Y}$ in the expression below) in Croatian enterprises depending on the variables stated above, by the use of the binary logit model (Greene 2000, p. 814):

$$
\operatorname{Prob}(\mathrm{Y}=1)=e^{\beta^{\prime} x} /\left(1+e^{\beta^{\prime} x}\right)=\Lambda\left(\beta^{\prime} X\right)
$$

based on the logistic function (Studenmund 2001, p. 442): 
$\ln (\mathrm{Y} /[1-\mathrm{Y}])=\beta_{0}+\beta_{1} \mathrm{X}_{1 i}+\beta_{2} \mathrm{X}_{2 i}+\varepsilon_{i}$

The logistic functions (estimations of parameters $\beta$ ) as well as the marginal effects of the explanatory variables X (INTENSIC, SIZEC, ABROADC and MANAGC) on the probability of controlling implementation in Croatian SMEs were presented, and the functions were tested by the likelihood ratio test. The functions' prediction success was also presented.

The research was performed in the period from the beginning of September to the end of December 2005 on the sample of 190 successful Croatian companies comprising 175 Croatian companies with the highest revenues in 2004 and the 15 largest Croatian banks (62 responded). Enterprises classification criterion by size was based on the ex-Croatian Accounting Act (Official Gazette No. 90/92, in force until January 2006).

There was also another sample of 65 Croatian SMEs randomly selected ( 52 responded) that was analyzed in the period 2005-June 2006. Among this group of entities, $85 \%$ were limited liability companies, $12 \%$ joint stock companies and the others were partnerships or limited partnerships (please see the SMEs sample description presented below):

\section{Controlling Developments and Recent Improvements}

Controlling implementation dates from the beginning of the $20^{\text {th }}$ century in USA but it started to develop more rapidly after the First World War in companies like Sears, General Motors, Standard Oil and DuPont. They began expanding their range of products and opening subsidiaries, first in different parts of the USA, and then also in other countries. That's why they needed a function that could help management to set the company goals, monitor their achievements and to coordinate different subsidiaries and departments.

After developing in the USA, in the middle of the 20th century, controlling started to be implemented in the West European companies, first through the subsidiaries of the American multinational companies, and then also by companies which operated exclusively in the national market. In 1992 and 1993 the Association of companies for research on the controlling and controllers' education analyzed the controlling presence and development level on a sample of 905 Austrian business entities. The requested turnover of the analyzed companies was over 70 million ATS, with their assets valued at least 15 million ATS and the number of employees over 100 . The return rate in the research was $33.37 \%$. The results were as follows:

- $52.90 \%$ of the entities had established a controlling department

- in $18.20 \%$ of the companies controlling was performed by some other department

- $\quad 29.10 \%$ of the companies didn't have a controlling department and its tasks were performed by management

In $66 \%$ of the analyzed companies controlling was the

\begin{tabular}{|l|l|l|}
\hline Feature & Small enterprises & Medium-sized enterprises \\
\hline Average number of employees & 15 & 94 \\
\hline Assets & $\begin{array}{l}<1 \text { million euros in 75\% of } \\
\text { enterprises }\end{array}$ & $\begin{array}{l}>1 \text { million euros in } 86 \% \text { of } \\
\text { enterprises (half of them }> \\
4 \text { million euros) }\end{array}$ \\
\hline Total revenues & $\begin{array}{l}<2 \text { million euros in 91\% of } \\
\text { enterprises }\end{array}$ & $\begin{array}{l}>2 \text { million euros in 70\% of } \\
\text { enterprises (but less than } 8 \\
\text { million euros) }\end{array}$ \\
\hline $\begin{array}{l}\text { Relation to business abroad } \\
\text { (existence or absence of any kind of foreign relation } \\
\text { in a given enterprise) } \\
\text { - the number of entities involved in foreign relations / } \\
\text { total number of entities in the sample }\end{array}$ & \multicolumn{1}{|c|}{$56 \%$} & $88 \%$ \\
\hline
\end{tabular}

Table 1: Sample Description

Source: authors' research. 
direct responsibility of the management. The controlling department was established at the first hierarchic level in $24 \%$ of the companies; at the second level in $63 \%$ of the cases, and at the third level only in $13 \%$ of the companies. (Osmanagić-Bedenik 2004, p. 33).

Controlling has gradually entered companies among all developed European countries. According to McKinsey's research performed in 1974 on the sample of 30 large German companies, controlling was implemented like an independent department in 90\%. The research of the demand for controllers by the German newspaper "Frankfurter Allgemeine Zeitung" showed a demand for only 5 employees (controllers) in the period 1949-1959. In the 1960s and onwards, the demand started growing, approaching 250 employees in the period 1985-1989 (Osmanagić-Bedenik 2004, p. 38). Such a significant increase confirmed the growing importance of controlling, both for the management of the companies and for the companies themselves. This was also proved by the research results presented at the 2nd congress of Controlling in St.Gallen, 1988 (table 2).

\begin{tabular}{|c|c|}
\hline $\begin{array}{c}\text { Number of } \\
\text { employees }\end{array}$ & $\begin{array}{c}\text { \% of companies with } \\
\text { controlling } \\
\text { organized as an independent } \\
\text { department }\end{array}$ \\
\hline less than 100 & $5 \%$ \\
\hline from 100 to 500 & $51 \%$ \\
\hline from 500 to 1000 & $70 \%$ \\
\hline more than 1000 & $96 \%$ \\
\hline
\end{tabular}

Table 2: Presence of Controlling in Swiss Companies in 1988. Source: Osmanagić-Bedenik, N., 2004, 43.

This research showed also that in companies with fewer than 100 employees the controlling tasks were performed by the finance and accounting department. In companies with 100 - 500 employees the controlling department was directly responsible to the finance and accounting manager (linear structure) in 50\% of cases. In companies with more than 500 employees controlling was established like an independent department.
Similar results could be found not only in Switzerland and Austria but in the companies of all developed European countries.

The intensive expansion of controlling was closely related to the functions delegated to this department. At its beginning, controlling was more or less occupied only by "registering" the changes in the company. At this time most of the information that controlling analyzed to help the management came from inside the company due to more or less stable environment. The changes that happened at the beginning of the 70 s with the petrol crisis and the saturation of demand "forced" controlling to change. It became a "navigator" which analyzed internal as well as external information, while its coordination function (horizontal and vertical) also started to have greater influence.

From the beginning of the 1990s, controlling became in charge of predicting future environment changes, transforming in this way into an "innovator". This new controlling function was given special importance after new markets opened in Eastern Europe (Czech Republic, Poland, Russia, Romania, Bulgaria, Croatia etc.), Asia (China, India, Pakistan, etc.) and the appearance of aggressive competition from the rising Asian tigers like Korea, Taiwan and Malaysia. In this period the coordination among the departments and subsidiaries (especially in different countries) started to be of extreme importance because a problem in one subsidiary or in one country undergoing aggressive competition had strong repercussions throughout the entire multinational company, and could cause losses in market share within a short period. In the $21^{\text {st }}$ century, firms cannot just operate in different countries; they must develop global strategies to coordinate their operations at all phases of the valueadding chain (D'Amours et al. 1999.). Controlling that acts as a coordinator, integrator of business functions and provider of information among different functions in the company, and that responds to the local environment, is one of the most important parts of any successful enterprise.

In the 1960s budgeting and controlling process development became highly important in the nonprofit and government sector as well (one example was the U.S. Department of Defence) with clear needs for 
experts in planning and budgeting (and afterwards in controlling). The process of developing controlling and planning in government institutions has accelerated since then.

Controllers must have a high level of education and different skills to fulfil the most difficult demands of the job. Usually, the formal request for these experts is at least a university degree in economy (very often with a specialization in finance and management accounting), and a few years of experience in finance and/or accounting. Controllers must also know well all the instruments that help management lead a company, such as strength, weakness, opportunity and threat matrices, analyses of different indicators (liquidity, profitability etc.), $A B C$ analyses and the Balanced scorecard model (which analyzes four perspectives: economic-financial, internal processes, customers and learning and development). In this way, the controller doesn't only consider financial indicators, but non-financial ones as well, such as customer satisfaction, quantity and quality of education, communication and continuity of the operation processes in the company. Controllers are also required to be team players, to understand cultural differences (especially in multinational companies), to be familiar with the company's branch, to have excellent communication and informatics skills, to be acquainted with methods of motivations and similar issues. In short, they must be persons with a high potential to learn business process and everything related to them. Such high requirements are necessary to provide management with the right information at the right time and to offer the best instruments to enable the successful accomplishment of business goals. That's why the controlling department is considered a good place to teach future managers and to prepare them to take an important position in the company. There are many similarities between a controller's and a manager's work. The main difference is that controllers are managers' advisers, while managers utilize advice to make decisions. A high quality controlling system is a precondition of successful management - "...bad systems or rules, not bad people, underlie the general failings of the board of the directors." (Jensen 1993 in Farber 2004, p. 542).
5. Controlling Developments in Croatian Companies - Present Situation and Perspectives

\subsection{Controlling Developments in the most successful Croatian Companies}

Croatia, like most Eastern European countries, began transforming itself from a planned to a market economy at the beginning of the 1990s, meaning Croatian companies have been fighting on the open market for almost two decades. It has been a complex and difficult process where "...top government and private sector leaders have little or no experience governing market oriented private firms..."; "Countries that are in the transition process from central planning to a market economy all face the same problems but they each have their own approach to solving the problems they encounter." (McGee and Preobragenskaya 2006, p. 244, 272). These facts motivated us to explore the penetration of controlling into Croatian companies trying to survive in severe business environments, burdened with problems common to all transition countries as well as with the peculiarities of the Croatian economy itself.

In $64.52 \%$ of the most successful companies in the sample, controlling was being done, either as an independent department or incorporated into another. The results could be compared with OsmanagićBedenik Nidžara's research (2001), published in the $2^{\text {nd }}$ edition of the book "Kontroling: abeceda poslovnog uspjeha" (Controlling - the Alphabet of Business Success), 2004. Her research (2001) has shown that $53 \%$ of the analyzed companies performed controlling in some capacity. It seems that in 4 years the share has risen around 12 percentage points, which means that Croatian companies have been recognizing the value and power of controlling in their day to day business.

According to the company size defined by the Croatian Accounting Act (Official Gazette 90/92 - the thresholds were raised later by the new Accounting Act - Official Gazette 146/05 and 109/07), controlling was present in $67 \%$ of large Croatian companies and in 55\% of medium sized companies in 2005 (all among the group of most successful companies). The greater 
share in large companies was related to the superior resources they had at their disposal to implement controlling.

The organisation of controlling as an independent department in the company is also an important indicator of its development. The results are presented in Figure 1.

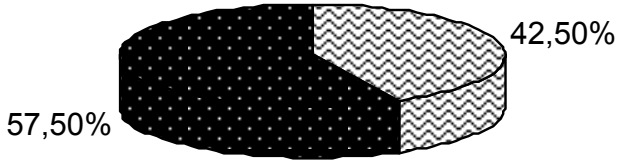

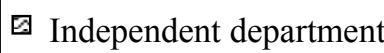

Part of some other department

Figure 1: Organisation of Controlling in Croatian Companies in 2005 Source: authors' research.

Obviously, in 58\% of companies, controlling was organized as part of some other department, usually finance or accounting - departments where controlling started to develop first, as in other countries. The rates of the independence of controlling departments in Switzerland ranged from $51 \%$ in medium sized companies to $90 \%$ in large ones. For transitional environments such as Croatia, which has only a short history of controlling developments, independent controlling departments were seen in $40 \%$ of cases, also a good result.

Controlling organization can influence one of the main controlling tasks, support of the management's decision-making process, which provides the necessary information to managers, on time and in the requested form. We have explored the sources of information that after integration and coordination were presented to managers by controlling departments.

The most important and often used sources of information for controlling were accounting (in 82.05\% of companies), marketing and sales $(69.23 \%$ of companies), finance $(43,59 \%$ of companies), followed by the investment, production, external sources and human resources departments in the observed sample of companies. From this we can conclude that the higher presence of controlling in, or near, the finance and accounting department led to more frequent use of information from these sources for advising management. The limitation of this information is that it is usually based on historical data that in a turbulent environment may have lost its relevance. One positive aspect is that marketing and sales were also among the most important providers of information, and their knowledge of market development (and that of the entire environment) could give controlling the better material than accounting and financial data to make better predictions. It is obvious that the information controlling analyzes comes from all the parts of the company and from sources outside the company, all of which resulted in the perception of controlling information as highly valuable to management.

In order to confirm the ability of controlling to provide valuable and useful information to the top management, we searched for the most intensive users of controlling information in the sample. We supposed that if the information that controlling provided weren't relevant for management decisions, top management would not use them.

Our assessment that the information provided by controlling was considered of high importance was confirmed, since $100 \%$ of the top management, moreover $65 \%$ of the owners and $60 \%$ of the department directors were users of such information. This proved that good controlling work based on internal historical data as well as external data can provide useful information to management for their decision making. As is obvious from Figure 2, $80 \%$ of those interviewed responded that controlling was of high importance in their business decision-making process. Also, it must be pointed out that no one considered controlling to be of little or no relevance to decision-making. 


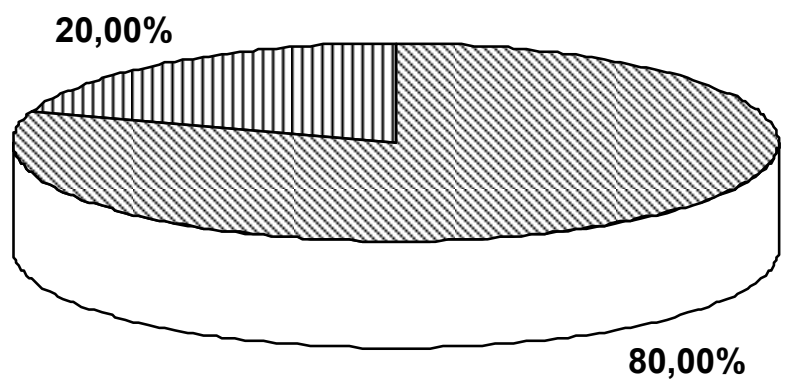

High importance $\mathbf{W}$ Medium importance

Figure 2: Evaluation of Controlling Importance in Decision Making in Croatian Companies in 2005

Source: authors' research.

The significant role of controlling in the decision making process was especially associated with companies that had prevalent ownership of foreign companies (multinational companies). In these companies, $95 \%$ of the managers declared that controlling was highly important in their decisionmaking process. Relating those results to OsmanagićBedenik's, where $97 \%$ of those interviewed declared that controlling helped them in achieving their goals, it was clear that controlling was considered a very important factor for the companies' success.

\subsubsection{Evaluation of Future Developments}

After presenting the actual situation of controlling in the most successful Croatian companies, its future development was evaluated. Research results indicate that more than $30 \%$ of the companies in the sample without controlling are planning to implement it in the near future. Taken together with the companies that have already implemented controlling, the share of successful Croatian companies that will have controlling organized in the near future could be higher than $75 \%$. In addition, $14 \%$ of the companies without controlling have developed it on the group level. The assumption is that these companies will also implement controlling soon, because growing competition and fast changes on the market will compel them to organize a controlling department on a higher level. This assumption makes the "controlling companies" share increase to $81 \%$.

The presence of controlling in successful Croatian companies could reach around $75-80 \%$ in the next few years. This increase is also related to the demand for employees in controlling. The data derived by analysis of the Croatian employment web site MojPosao.net (the biggest employment web site in Croatia) in the last few years, and projections for the year 2006 based on the first 5 months, are presented in Figure 3.

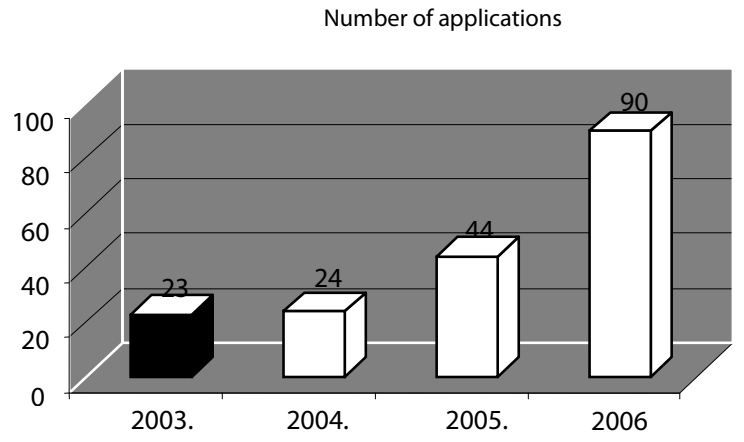

Figure 3: Demand for Controllers according to the Employment Web Site MojPosao.net

It is clear that the demand for controllers is growing rapidly. Assuming the trend continues, within a few years it will reach more than 200 controllers annually. A similar trend was noticeable according to another Croatian employment web site (Posao.hr), where in the first 10 months of 2005, there was a demand for 14 controllers, and for 21 in the first 8 months of 2006. The analysis of the demand for controllers in 2005 was stratified by regions, employing the observation method on the employment web sites Moj.Posao.net and Posao.hr. The results showed that the highest demand for controllers was in the capital city (Zagreb) and its surrounding areas (55\%). This was expected because most industry and the most successful companies are situated in this region. The demand from other parts of Croatia (29\%) also indicated an awareness of the need for controllers. This means that some of the most successful companies are switching their activities to other regions, since smaller Croatian regions are trying to attract investments through different tax policies to help their development. Part of the companies (16\%) related to multinational companies with subsidiaries in different regions and/or 
countries were recruiting new employees that would probably be switched from one place to another.

Companies usually employ young people with some experience as controllers that are prepared to confront fast and extensive changes to their workplace and type of work. Working experience demanded for controllers in Croatia was analyzed and is presented in Figure 4.

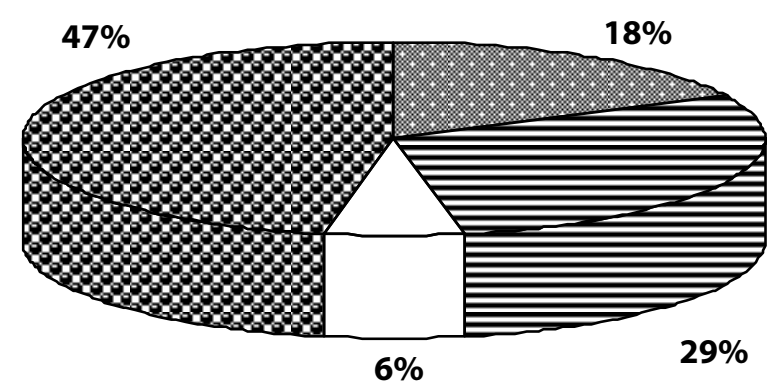

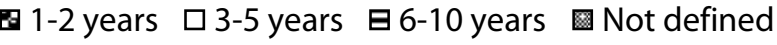

Figure 4: Analysis of the Required Working Experience for Controllers in Croatia in 2005 according to Croatian Employment Web Sites

Source: authors' research.

Most of the companies were looking for employees with 3 to 5 years (29\%) of experience, while only $6 \%$ of the companies searched for employees with more than 5 years of experience. The high share of companies that did not define a required amount of working experience indicates that Croatian companies were less concerned with experience than other criteria like education or special knowledge and skills. Most companies (78\%) required a second university degree BSc (at least 4 years of undergraduate education), followed by (12\%) those that required the first university degree - BBA (at least 2 years of undergraduate education). In addition, knowledge of at least one foreign language (mostly English) and excellent computer skills (especially MS office and SAP programs) were necessary. Other required skills were excellent time management, communication, decision making, a capacity for teamwork, and organizational and analytical skills. These employees were expected to be strong, open-minded, flexible, challenge receptive and focused on solutions. Accounting (local and IFRS) and statutory system knowledge were also required. The expectations of these employees were undoubtedly high, and include considerable hard work. On the other side, there is a high satisfaction level with dynamic work full of challenges and opportunities for promotion towards the top management levels. According to research performed by the employment web site Moj.Posao.net, controllers were the best paid specialist employees in in Croatia.

The growing trend of demand for controllers and high requirements for the controller position has been recognized by academic institutions. This discipline has found its place in the curriculum of Croatian universities. Today, controlling is taught at three Croatian universities (University of Zagreb, University of Šibenik and University of Rijeka). Also, professional associations, such as the Croatian association of accountants and financial experts (Hrvatska zajednica računovođa i financijskih djelatnika) are supporting the development of controlling by organizing professional and scientific conferences and publishing articles that explore controlling tasks and duties.

\subsection{Controlling Developments in Croatian SMEs}

Croatian SMEs account for $98 \%$ of the total number of business entities, accounting for $38 \%$ of the total revenue and $56 \%$ of employees in Croatia (Analysis of Financial Results of Enterprises, FINA, 2006).

This situation is opposite to that before the start of transition processes (early 1990s), which was characterized by large state or socially-owned enterprises employing hundreds or thousands of people. The processes of restructuring and privatization produced high unemployment, with many people attempting to start their own business to survive. This is why a great number of small enterprises emerged. Radical transitional changes introduced competition, running businesses in an open market, and responsibility for one's own decisions or actions with regard to private interests and profit. Switching into new, strange environments was not easy and high quality information on the process of decision making became a precious resource. Previously, decisions were mostly based on intuition and ad-hoc solutions. Information systems were rudimentary, with most 
information provided by accountancy that was nothing more than bookkeeping - a passive, static, uniform system, existing solely to meet the rules and information requirements typical for an economy of high government regulation and legal influence. Accounting was just a routine practice of following rules that changed frequently. Accountants lost a great deal of time trying to implement them, leaving very little time for cost or management accounting. Thus, accounting reform began immediately in the early 1990s in an attempt to align with the new requirements of the changing business environment. It had to transform the uniform and passive accounting system into a modern one comparable to its role and function in developed countries. Management accounting has started developing and as businesses grow, the need to develop controlling became obvious. Controlling used a great deal of information from accounting as its basic source. Such a process could not be emulated by smaller enterprises that were too scarce of resources to organize their own accounting systems (usually performed by outside agencies), not to even mention controlling systems. Intensifying competition in a young market economy prompted controlling to be increasingly considered a necessity, even by smaller entities.

Four hypotheses $(\mathrm{H} 1-\mathrm{H} 4)$ developed in Chapter 2 were empirically tested on the sample of Croatian SMEs and the results are presented below.

As we have previously mentioned, accounting is considered the main source of information that controlling collects, processes and prepares for the use of management. Because of this we have explored the relation between the use of accounting information and controlling implementation in Croatian SMEs.

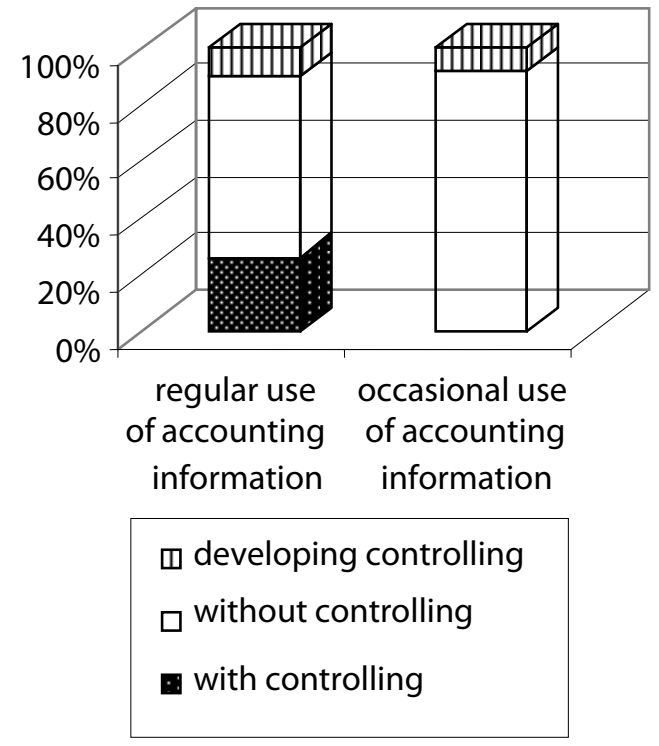

Figure 5: Controlling Implementation in Relation to Accounting Information Use in Croatian SMEs in 2005

Source: authors' research.

According to the figure above, in the sampled enterprises where management decisions were often made intuitively, using the accounting information only occasionally, controlling was not used. Regular use of accounting information indicated that management was aware of the importance of having high-quality, reliable, timely information at its disposal, and in doing so creating the basis for improving information sources by the development of controlling as its support. This correlation is also confirmed by logit regression ${ }^{1}(3)$, which is presented in the appendix.

The dependent variable of regression (3) is the log of the odds ${ }^{2}$ that controlling would be developed or develop (CONTROLC) in a given enterprise versus the situation where it is not developed (i.e. where it is not implemented at all). It is obvious from the regression that the probability of its implementation in a given enterprise is positively related to the intensity of accounting information use (INTENSIC). The null hypothesis that the INTENSIC coefficient is zero is rejected in favor of the alternative $(\mathrm{H} 1)$ that it is positive, at a $10 \%$ significance level. The marginal effect is 0.28205 . SMEs where accounting information 
is only occasionally used have a probability of controlling implementation of 0.07692 , while it increases to 0.35897 if the accounting information is used regularly. The likelihood ratio test indicates that the null hypothesis that slope coefficients are zero is rejected at the $5 \%$ significance level. The model predicts $71 \%$ of the observations correctly (see the prediction success table no. 3 in the appendix).

Controlling implementation in Croatian SMEs is presented in the figure below.

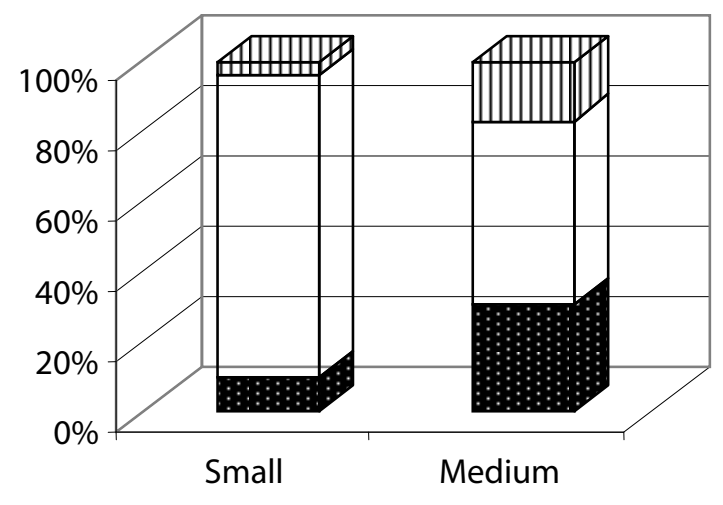

Size

\begin{tabular}{|l|}
$\square$ developing controlling \\
$\square$ without controlling \\
$\square$ with controlling
\end{tabular}

Figure 6: Controlling Implementation in Croatian SMEs in 2005 Source: authors' research.

Controlling was not implemented in more than two thirds of sampled Croatian SMEs. It existed in $20 \%$, for an average of 5.4 years. As was expected, the share of enterprises that developed controlling was three times higher in medium sized enterprises than in small ones.

Perspectives on future development were also explored. Only $10 \%$ of SMEs invested efforts in developing controlling over the course of the next 2 years. Once again the ratio was four times higher for medium-sized enterprises than in small enterprises.

Thus, hypothesis $\mathrm{H} 2$ is accepted according to the regression (4) in the appendix. There is a positive coefficient of variable SIZE related to the log of the odds that controlling would be implemented (CONTROLC) in a given enterprise, confirming the positive influence of the enterprise's size (middle-sized versus small-sized) on the probability of controlling implementation at a $1 \%$ significance level. The marginal effect of 0.34033 indicates the increase of probability of controlling implementation for a middle size enterprise (0.47826) in relation to small enterprise (0.13793). The function predicts $71 \%$ of outputs correctly (please see the prediction success table no. 4 in the appendix).

In addition to the size criterion, we tested the eventual influence of relations to business abroad on controlling implementation in a given SME. The results are presented below (figure 7).

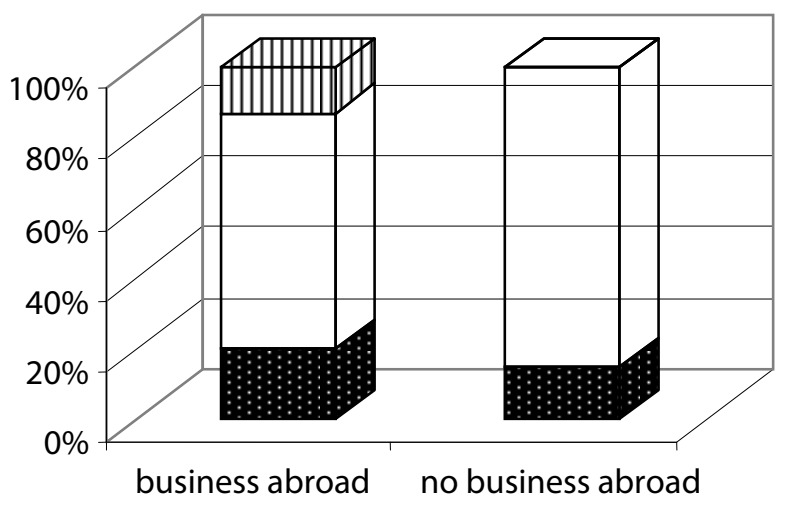

$$
\begin{aligned}
& \square \text { developing controlling } \\
& \square \text { without controlling } \\
& \text { a with controlling }
\end{aligned}
$$

Figure 7: Controlling Implementation in Relation to the Croatian SMEs' Business Abroad in 2005

Source: authors' research.

Obviously, better results for controlling implementation were related to the enterprises being involved in business abroad. There were also more intensive activities with regard to its development. Such a relation is expectable, since running a business on foreign markets brings more complex information requirements compared to those of domestic markets, making the benefits of developing a controlling function more obvious. Although structural analysis indicates such a relation, hypothesis $\mathrm{H} 3$ was rejected (regression 5) in favour of the null hypothesis that this variable's coefficient is not different than zero ( $p$ 
value $=0.22779$ ). Also, the rejection was confirmed by a likelihood ratio test $=1.66933$ with 1 d.f. $p=$ 0.19635 .

In addition, a frequent situation among Croatian SMEs is that owners manage the enterprises themselves. It was interesting to explore how such a situation influences controlling developments in a given enterprise.

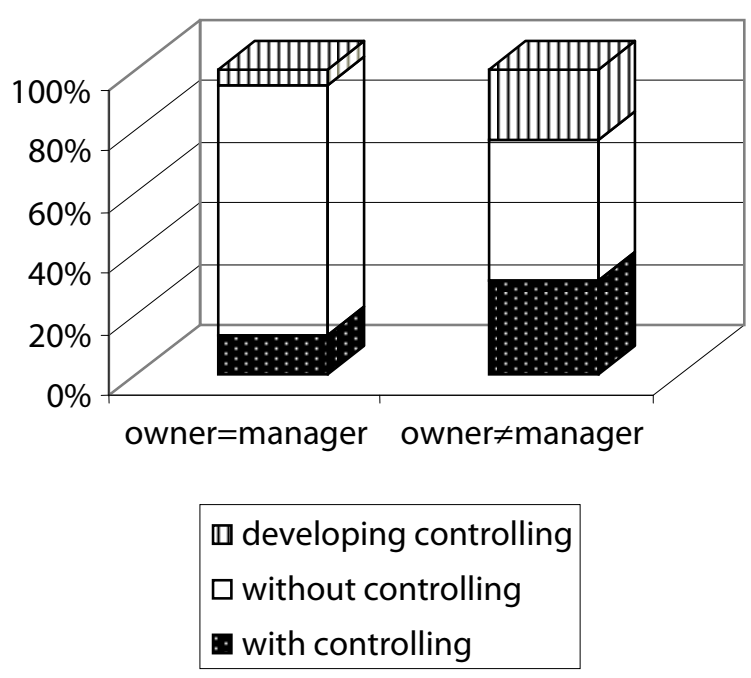

Figure 8: Controlling Implementation in relation to Integration of Ownership and Management in Croatian SMEs in 2005

Source: authors' research.

In accordance with the historical trend of separating management from owners as the business grows and its management develops independently, controlling was more intensively present or the process of its development was going on in more than half of the cases where the owner did not operate as a manager at the same time.

Hypothesis $\mathrm{H} 4$ is accepted based on the logit regression 6 presented in the appendix. The log of the odds that controlling would be developed or was in the process of developing (CONTROLC) in a given enterprise is found positively correlated with the separation of the owner from management (variable MANAGC). Thus, the variable MANAGC influences positively the probability of having controlling implemented in a given enterprise (level of significance $5 \%$ ). The probability of controlling implementation increases in case the owner does not operate as the manager at the same time with the marginal effect of 0.33333. The probability of having controlling developed or developing in an SME where the owner acts also as a manager is 0.20513 , while it increases to 0.53846 where those functions are separated. The function predicts $73 \%$ of cases correctly (please see the prediction success table no. 6 in the appendix), so the results suggest a good fit.

\section{Conclusions}

In this paper, we have presented research results on the actual situation of controlling implementation in the transitional environment of Croatia and have also assessed its future developments. We have performed research on its presence in the most successful companies, as well as in Croatian SMEs. The demand for controllers was explored across the whole territory of Croatia.

Controlling is implemented in more than $60 \%$ of the most successful Croatian companies in the sample and the share is still growing, with expectations that more than $75 \%$ of Croatian successful companies will have an organized controlling department (or at least with a controller) in the next few years (2-3).

The controlling development process is going very slowly in Croatian SMEs, where it is modestly present (in less than one third of sampled SMEs) and has taken only small steps forward (10\% of sampled SMEs plan to introduce it in the next 2 years). In order to understand controlling implementation in Croatian SMEs, 4 hypotheses were tested. The SMEs with implemented or developing controlling were primarily middle sized entities and particularly those with management separated from the owners, where accounting information was used regularly. The influence of running the business abroad on controlling implementation was not confirmed by a logit analysis test.

It seems there are encouraging controlling development trends in Croatia, mostly related to successful enterprises with substantive resources that enable them to organize this function. 
Although controlling has been developing very slowly in Croatian SMEs, the need for its establishment is evident. This is because, as in any transitional economy, SMEs emerge and disappear in very short cycles, sometimes within months. Controlling should not be considered a "luxury," something hardly affordable because of scarce resources. Its implementation does not have to necessarily follow the expensive organizational solutions usually encountered in large companies. It should be organized in an effective and efficient way to break a "magic cycle" of falling deeper and deeper into crisis due to a lack of relevant information that could help handle the problems when/before they emerge, avoiding in this way the loss of control over the business.

The enterprises in transition economies like those in Croatia are still in the process of learning market laws and controlling has been developing simultaneously. However, it still hasn't reached the level it enjoys in developed economies. The growing demand for controllers in Croatia is evident, but it is still the most intensive in the Croatian capital (Zagreb) and its surrounding area. Also, controlling development is supported by the Croatian educational system by introducing the study of controlling at several Croatian universities. The controlling department is independently organized in most of the successful companies analyzed, but that is not the case in around $60 \%$ of companies and $20 \%$ of their management still do not consider it of great importance to their decision making. This situation needs a lot of investment and effort before controlling reaches its "innovator" stage. In other words, the "innovator" stage means the qualitative change of controlling tasks, while we are still discussing only its presence in Croatian enterprises.

Thus it is not enough to have controlling organized in a given enterprise, but to improve the use of controlling, to force it to move toward more developed stages. Introducing controlling into a larger number of Croatian companies and upgrading its use requires both the help of the education system and continuing education.

Although it was presented earlier that the educational system (formal and informal) has been gradually identifying the necessity for a stronger push towards controlling driven by the increasing needs of enterprises, the actual situation is far from ideal. The process of the introduction of new studies or courses in the university programs needs time, while high market demand is present at this moment.

For this reason our suggestion for companies is further valorisation of controlling work and tasks by rewarding controllers in different ways, in the first place financially but also by motivation, providing them the possibility of hierarchical growth in the company. Alternatively, the companies would probably have to accept the high mobility of these employees.

The increased market demand gives companies the possibility of internal controlling education of employees with high potential. This is recommended to be organized in cooperation with institutions of higher education and professional associations so that the employees can obtain certificates and/or diplomas that would be recognised on the labour market. In this way the company will receive controllers that are already familiar with the company structure, targeted market and strategic goals and will not need introductions to the business. In addition, these employees will be pleased that their potential and knowledge have been recognized and that the company gives them the possibility to upgrade their knowledge. This will improve the company's spirit, with employees that aren't there only because of money but feel a sense of belonging to the company. This is extremely important for controllers because they are informed about the most important issues concerning the company (internal and external) and their loyalty is critical. A controller's work demands a lot of sacrifices both professional and personal, with a lot of overtime work under stress which often is even impossible to reward financially. This is the reason why internal education is an optimal way to decrease (if not even to stop) controller outflow from the company and also diminish (or even avoid) the introduction costs for new employees (controllers). It is also important that in this process the government contributes legislation. They should allow the recognition of internal diplomas and certificates provided by certified institutes and 
schools on the labour market. In this way the employees will appreciate even more the opportunity provided by their employers, consequently deepening their loyalty.

With regard to SMEs without sufficient resources or the possibility to organize controlling on a cost-benefit basis, one possible solution could be the change of the profile of accountants towards small business advisors. Actually, they already offer a wide set of services together with accounting services, trying to help small business entrepreneurs with financial, tax and other advices but "...the limited varieties of management advisory services they offer, their inability to effectively market what they do offer, and their lack of knowledge of the unique context, challenges and prospects of small business, have been recognized as perennial problems. Identification of these problems has prompted calls for enriched and more specialized education of accountants in order for these professionals to develop an improved skill set." (Bisman 2007 , p. 58). Since controlling has traditionally used the most quantity of information from accounting data, joining the controller's tasks together with those of the accountant could be one solution for smaller businesses. In this way the accountant should serve as a "small business advisor". Educating accountants as small business advisors has been successfully performed (e.g.) at Charles Stuart University, Bathurst, Australia during the last 10 years. Croatian universities should also follow their example, since $98 \%$ of enterprises in the Croatian economy are SMEs, and smaller enterprises have no one other than their accountants to ask for advice. Controlling knowledge could substantively improve their advising services. This should be kept in mind in the process of designing and developing university programs as well as programs for permanent education.

Following these recommendations in upgrading the higher education system, together with permanent education programs could significantly contribute to controlling development in Croatia. $[$.

\section{Endnotes}

${ }^{1}$ about logit regression, please, see more in: Demaris 1992; Bierens 2004; Greene 2000; Hair at all. 1998; Studenmund 2001.

${ }^{2}$ «Odds refer to the ratio of the number of times a choice will be made divided by the number of times it will not.» (Studenmund 2001, p. 442)

\section{References}

Anthony, R. N., and Govindarajan, V. 2001. Management Control System, 10th ed. McGraw-Hill

Avelini Holjevac, I. 1998. Controlling: Income Management. Opatija: Hotelijerski fakultet u Opatiji.

D'Amours, S., Mounteuil, B., Lefraincois, P., Soumis, F. 1999. Networked Manufacturing: The Impact of Information Sharing. International Journal of Production Economics 58: 63-79.

Bierens, H.J. 2004. The Logit Model: Estimation, Testing and Interpretation.

Bisman, J.E. 2007. Educating Accountants to Act as Small Business Advisors: a Ten-Year Perspective", in: Mošnja-Škare, L., ed.: Accounting for SMEs: Multidimensional Aspects and Global Challenges, Juraj Dobrila University of Pula, Mikrorad, Zagreb.

Croatian Accounting Act, Official Gazette 90/1992., 146/05.

Demaris, A. 1992. Logit Modeling - Practical Applications. Newbury Park: SAGE Publications.

Demski, J.S. 2004. Endogenous Expectations. The Accounting Review 79 (2): 519-539.

Drogendijk R., Slangen A. 2006. Hofstede, Schwartz, or managerial perceptions, The Effects of Different Cultural Distance Measures on Establishment Mode Choices by Multinational Enterprises. International Business Review 15: 361-380.

Farber, D.B. 2004. Restoring Trust after Fraud: Does Corporate Governance Matter? The Accounting Review 80 (2): 539-561.

Filatotchev I., et. al. 1999. Corporate Entrepreneurs and Privatized Firms in Russia Ukraine and Belarus. Journal of Business Venturing 14: 475-472.

FINA (Financial Agency of Croatia). 2006. Analysis of Financial Results of Enterprises.

McGee, R.W., Preobragenskaya, G.G. 2006. Accounting and Financial System Reform in Eastern Europe and Asia. New York: Springer.

Greene, W.H. 2000. Econometric Analysis, $4^{\text {th }}$ ed. New Jersey: Prentice-Hall.

Gunesekaran A., et. al.2005. Performance Measurement and Costing System in New Enterprise. Technovation 25: 523-533.

Hair, Jr., J.F., Anderson, R. E., Tatham, R.L., Black, W.C. 1998. Multivariate Data Analysis, $5^{\text {th }}$ ed. New Jersey: Prentice-Hall. 
Indjejikian, R.J. Organizational Slack in Decentralized Firms: The Role of Business Unit Controllers. The Accounting Review 81 (4): 849872.

Jones L.R., McCafferty Jerry L. (2005). Reforming of the Planning, Programming, Budgeting System, and Management Control in the U.S. Department of Defence: Insight from the Budget Theory. Public Budgeting \& Finance 25 (3): 1-19.

Matulich, S. 1994. Financial Accounting. $2^{\text {nd }}$ ed. Orlando: Unicorn Research Corporation.

O'Brien, J. A.1993. Management Information System, A Managerial and User Perspective. $2^{\text {nd }}$ ed. Richard D. Irwin, Inc.

Osmanagić-Bedenik, N. 2004. Controlling: the Alphabet of Business Success. Zagreb: Školska knjiga.

Osmanagić-Bedenik, N. 2006. Accounting and Controlling Competition or Collaboration. Računovodstvo, revizija i financije 8: 2128.

Parfet, W.U. 2000. Accounting Subjectivity and Earnings Management: A Preparer Perspective. Accounting Horizons 14 (4): 481-488.

Preisler, P. R., and Peemoller, E. K. 1990. Controlling. Landsbert/Lech: Moderne Industrie.

Ryan, B. 1995. Strategic Accounting for Management. London: The Dryden Press, Harcourt Brace and Company.

Simons, R. 1999. Performance Measurement and Control Systems for Implementing Strategy. Prentice Hall.

Studenmund, A.H. 2001. Using Econometrics - a Practical Guide, $4^{\text {th }}$ ed. Boston: Addison Wesley Longman.

Špac, D. 2006. Kontroling: potpora managementu pri poslovnom odlučivanju - razvojni trendovi u Hrvatskoj, master thesis.

Usha C.V. Haley. 2003. Assessing and Controlling Business Risk in China, Journal of International Management 9: 237-252.

Veldhuizen, E. et. al. 2006. Modelling market information processing in new product development. An empirical analysis, J. Eng. and Technol. Manage. doi:10.1016//j.jengetacman.2006.08.005.

McWatters, C.S., Morse, D.C., Zimmerman, J.L. 2001. Management Accounting - Analysis and Interpretation, $2^{\text {nd }}$ ed. Boston: McGraw-Hill Irwin.

Weber, J. 1993. Einfuhrung in das Controlling. Stuttgart: Poeschel.

Welsch, G. A., Hilton R. W., Gordon, P. N. 1988. Budgeting Profit Planning and Control, $5^{\text {th }}$ ed. Englewood Cliffs: Prentice Hall Inc.

Zimmerman, J.L. 1995. Accounting for Decision Making and Control. Richard D. Irwin Inc.

Internet:

Croatian web employment site MojPosao: www.mojposao.net

Croatian web employment site Posao.hr: www.posao.hr
International group of Controlling web site: www.igccontrolling.org 
Appendix

H1: Controlling implementation is positively associated with the intensity of accounting information use.

H1 ACCEPTED

$\ln ($ CONTROLC / [1-CONTROLC $])=-2.4849+1.9051$ INTENSIC

$$
\begin{aligned}
& (1.0912) \\
& \mathrm{t}=1.7458 \\
& \mathrm{p}=0.08084 \quad \mathrm{n}=52, \text { iterations }=4
\end{aligned}
$$

CONTROLC $=$ controlling function development ( $1=$ developed or developing; $0=$ not developed $)$

$\ln ($ CONTROLC / [1-CONTROLC] $)=\log$ of the odds that controlling would be developed or developing - versus - it wouldn't be implemented at all in a given enterprise

INTENSIC $=$ the intensity of accounting information use $(1=$ regular use; $0=$ occasional use $)$

Probabilities of having controlling function developed or developing:

Prob $($ CONTROLC $=1)=0.076924$ if INTENSIC $=0$

Prob $($ CONTROLC $=1)=0.35897$ if INTENSIC $=1$

Marginal effect $=0.28205$

Log-likelihood function $=-28.986$

Log-likelihood $(0)=-31.240$

Likelihood ratio test $=4.50856$ with 1 d.f. $p=0.03373$

Prediction success table (3)

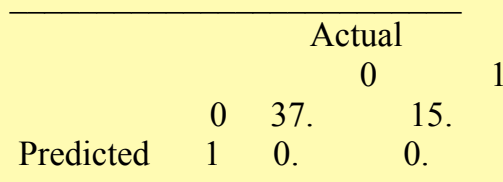

H2: Controlling implementation grows with the enterprise's size.

\section{H2 ACCEPTED}

$\ln ($ CONTROLC / [1-CONTROLC $])=-1.8326+1.7456$ SIZEC

$$
\begin{aligned}
& (0.68134) \\
& \mathrm{t}=2.5619 \\
& \mathrm{p}=0.01041 \quad \mathrm{n}=52, \text { iterations }=4
\end{aligned}
$$

$\mathrm{SIZEC}=$ enterprise's size $(1=$ middle sized enterprise; $0=$ small enterprise $)$

Probabilities of having controlling function developed or developing:

Prob $($ CONTROLC $=1)=0.13793$ if $\mathrm{SIZEC}=0$

Prob $($ CONTROLC $=1)=0.47826$ if $\mathrm{SIZEC}=1$

Marginal effect $=0.34033$ 
Log-likelihood function $=-27.555$

Log-likelihood $(0)=-31.240$

Likelihood ratio test $=7.36962$ with 1 d.f. $p=0.00663$

Prediction success table (4)

\begin{tabular}{|c|c|c|}
\hline \multicolumn{3}{|c|}{ Actual } \\
\hline & 0 & 1 \\
\hline 0 & 37. & 15. \\
\hline Predicted 1 & 0. & 0. \\
\hline
\end{tabular}

H3: Controlling implementation increases if the enterprise is somehow related to the business abroad.

H3 NOT ACCEPTED

$\ln ($ CONTROLC / [1-CONTROLC $])=-1.7047+1.0116$ ABROADC

$\mathrm{t}=1.2061$

$p=0.22779$

$\mathrm{n}=52$, iterations $=3$

ABROADC=relation to the business abroad ( $1=$ if it exists; $0=$ if it doesn't exist)

Probabilities of having controlling function developed or developing:

Prob $($ CONTROLC $=1)=0.15385$ if $\mathrm{ABROADC}=0$

Prob $($ CONTROLC $=1)=0.33333$ if $\mathrm{ABROADC}=1$

Marginal effect $=0.17949$

Log-likelihood function $=-30.405$

Log-likelihood $(0)=-31.240$

Likelihood ratio test $=1.66933$ with 1 d.f. $\boldsymbol{p}=\mathbf{0 . 1 9 6 3 5}$

Prediction success table (5)

\begin{tabular}{|c|c|c|c|}
\hline & \multicolumn{3}{|c|}{ Actual } \\
\hline & & 0 & 1 \\
\hline & 0 & 37. & 15. \\
\hline Predicted & 1 & 0 & 0 \\
\hline
\end{tabular}




\section{H4: Controlling implementation increases if the owners are not involved in management at the}

same time.

\section{H4 ACCEPTED}

$\ln ($ CONTROLC / [1-CONTROLC $])=-1.3545+1.5087$ MANAGC

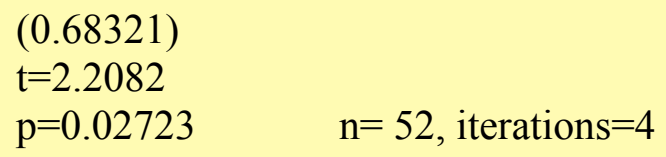

MANAGC $=$ management function performance $(1=$ if owner $\neq$ manager, $0=$ if owner=manager $)$

Probabilities of having controlling developed or developing:

Prob $($ CONTROLC $=1)=0.20513$ if MANAGC $=0$

Prob $($ CONTROLC $=1)=0.53846$ if $\mathrm{MANAGC}=1$

Marginal effect $=0.33333$

Log-likelihood function $=-28.762$

Log-likelihood $(0)=-31.240$

Likelihood ratio test $=4.95555$ with 1 d.f. $p=0.02601$

Prediction success table (6)

\begin{tabular}{rcc}
\hline & Actual & \\
& 0 & 1 \\
0 & 31. & 8. \\
Predicted 1 & 6. & 7.
\end{tabular}

